\title{
ERRATUM
}

\section{Child care by grandparents: changes between 1992 and 2006 - ERRATUM}

\author{
TEUN GEURTS*, THEO VAN TILBURG*
}

ANNE-RIGT POORTMAN $\dagger$ and PEARL A. DYKSTRA $\ddagger$

doi: $10.1017 /$ So144686X14000270, published online by Cambridge University Press 23 April 2014

The first affiliation at the bottom of the opening page was incorrect. The correct version should read as follows:

* Department of Sociology, VU University Amsterdam, The Netherlands.

The Press would like to apologise to the authors and to the readers for this error.

\section{Reference}

Geurts, T., van Tilburg, T., Poortman, A. and Dykstra, P. A. 2014. Child care by grandparents: changes between 1992 and 2006. Ageing Eo Society, published by Cambridge University Press, 23 April 2014. doi: 10.1017/So144686X14000270 